Article

\title{
Design and Validity of a Choice-Modeling Questionnaire to Analyze the Feasibility of Implementing Physical Activity on Prescription at Primary Health-Care Settings
}

\author{
Sergio Calonge-Pascual ${ }^{1}$ (D) Francisco Fuentes-Jiménez ${ }^{1}$, José A. Casajús Mallén ${ }^{2,3}$ and \\ Marcela González-Gross 1,3,*iD \\ 1 ImFINE Research Group, Faculty of Physical Activity and Sport Sciences-INEF, Universidad Politécnica \\ de Madrid, C/Martín Fierro 7, 28040 Madrid, Spain; s.calonge@upm.es (S.C.-P.); \\ francisco.fuentes@upm.es (F.F.-J.) \\ 2 GENUD Research Group, Faculty of Health Sciences, University of Zaragoza, Pedro Miral s/n, \\ 50008 Zaragoza, Spain; joseant@unizar.es \\ 3 Biomedical Research Center of Physiopathology of Obesity and Nutrition, CIBERobn, (CB12/03/30038), \\ Carlos III Health Institute, Avenida de Monforte de Lemos 5, 28029 Madrid, Spain \\ * Correspondence: marcela.gonzalez.gross@upm.es
}

Received: 6 July 2020; Accepted: 3 September 2020; Published: 11 September 2020

check for updates

\begin{abstract}
Worldwide health policies are trying to implement physical activity on prescription (PAP) at healthcare settings. However, there is not a proper methodology to analyze PHC organizational staff factors. This study aims to validate two questionnaires to assess the self-perception of nurses and general practitioners to implement PAP at primary healthcare (PHC) settings. The designed choice-modeling Google-form questionnaire was sent to 11 expert nurses and 11 expert sports medicine physicians. Experts evaluated each question on a 1-5 points Likert-type scale according to their expertise. Aiken's V coefficient values $\geq 0.75$ were used to validate separately each question using the Visual Basic-6.0 software. A total of 10 sports medicine physicians and 10 nurses with $28.4 \pm 5.1 \mathrm{y}$ and $16.3 \pm 11.8$ y of PAP experience, respectively, validated the questionnaire. One expert in each group was not considered for offering $3 \pm S D$ answers in $\geq 2$ questions respect to the mean of the rest of experts. Final Aiken's V coefficient values were 0.89 (0.77-1.00) for the nurses' questionnaire and 0.84 (0.77-0.95) for the physicians' one. The questionnaires designed to assess the PAP self-perception of PHC nurses and physicians were validated. This methodology could be used to analyze PHC organizational staff factors in order to achieve an efficient PAP implementation in other PHC contexts.
\end{abstract}

Keywords: exercise; preventive medicine; health promotion; public health; physicians; nurses; health behavior; healthcare; attitude of health personnel; disease management

\section{Introduction}

The global age-standardized prevalence of physical inactivity is around $25 \%$ in the world [1]. Physical inactivity and sedentary behavior represent currently a leading risk factor for non-communicable chronic diseases (NCDs) [2]. Since, in 2015, Saltin et al. established that exercise prescriptions could treat at least 26 different NCDs [3], physical activity (PA) has increased in importance and represents a cornerstone in the prevention, at least, of 35 chronic conditions [2]. Recently, it has been published that even more than 40 NCDs could be prevented and treated by exercise prescriptions as a precision medicine [4]. Health benefits of exercise prescriptions are documented and well-known [5]. Therefore, several approaches are trying to promote PA on prescription (PAP) in healthcare (HC) settings, as for example, the proposal of the WHO for 
the European Region 2016-2025 [6], the worldwide strategy of the American College of Sport Medicine that is the Exercise is Medicine ${ }^{\circledR}$ initiative [7-9], and others [10-12].

Based on the strength of existing evidence, regular PA should be the first line of preventive and rehabilitation medicine; however, insufficient progress is being developed about the implementation of a model to increase PAP in HC settings $[10,13,14]$. Interest in PAP implementation has increased during last years, and adherence to non-pharmacological treatments had been traditionally focused by patient-related factors [15]. In contrast, some studies have shown the lack of public resources in the HC system [16-18] and for the HC team [16,19], the lack of exercise prescription training knowledge [20-23], lack of time in their Primary Healthcare (PHC) consultations [24], and the lack of awareness with exercises prescription [24,25], etc.

PHC providers should be considered as intra and interpersonal dimensions inside of the organizational HC system dimension under a social ecological perspective on PAP programs [26,27]. The relationship with the local health and sports community resources [28], managed by health promotion policy, should be strategically studied in order to developed a PAP strategy by a multidisciplinary or interdisciplinary approach [12]. In this sense, to identify all the main barriers and facilitators that influence PAP in HC settings should be a priority for an efficient implementation $[10,17]$. Some attempts have been made in the last years. Surveys have been designed and carried out in physicians from Canada [7,29], Germany [30,31], and USA [32,33], in health promoters from Australia [34,35] and physical therapists from Canada [36] and Nigeria [37]. However, there is not a consensus or a validated questionnaire to measure the self-perceived PAP barriers and facilitators in health promoters. Therefore, as part of a broader study, the aim of this study was to validate two questionnaires by a panel of experts who were familiar with the PAP construct, to assess the self-perception barriers and facilitators of nurses and general practitioners (GPs), as a first step to facilitate the implementation of PAP at PHC settings, under the umbrella of the Exercise is Medicine initiative.

\section{Materials and Methods}

Two questionnaires were validated according to the guidelines published by Tsang et al., in 2017 [38]. Following these guidelines, domains of interest and constructs were previously identified to assess what the questionnaire should measure and a check that no validated questionnaire is available in the scientific literature was performed. The baseline for the questionnaire design were focus groups discussions with 5 GPs and 5 nurses, which took place as part of a PhD thesis [12]. Briefly, GPs and nurses, separately, guided by an expert psychologist, commented during four hours about their opinions, barriers, and facilitators to implement PAP in PHC. Their answers were categorized and organized in a structured 30-question questionnaire, according to the five sections and category and subcategory constructs shown in Table 1.

Two choice-modeling, Google-form questionnaires were developed by our group [12] as an on-line self-administered format, because we thought that health professionals are able to complete the questionnaire on their own. A close-ended item format by multiple-choice, Likert-type scales and true/false answers were established, with a simple, short, and familiar language item design for the target respondents. As there is no rule for the length of questionnaires, it was designed to measure the full construct of interest, trying not be so long that respondents experienced fatigue or loss of motivation in completing it. A preliminary review and revision pool of items and pilot testing was conducted by all members of the Improvement of health by fitness, nutrition and exercise Research Group (ImFINE).

Finally, a content validity of the questionnaires was done by a panel of experts as previously had been done by other authors in other fields [39,40]. Eleven nurses and 11 GPs were selected. Inclusion criteria for being considered as an expert were: age $\geq 35 \mathrm{y} ;>3 \mathrm{y}$ of PAP career experience and/or $\geq 20 \mathrm{y}$ of academic background related to sports medicine, general practitioner medicine, nursing, public health promotion, and recent or previous relationship with a national public health or PHC system. Descriptive data of the experts are shown in Tables 2 and 3. 
Table 1. Summarized and justified structure of the questionnaire related to each category obtained by focus groups sessions.

\begin{tabular}{|c|c|c|c|c|}
\hline \multicolumn{5}{|c|}{ CONSTRUCTS OF THE QUESTIONNAIRE } \\
\hline Section & Category & Subcategory & No. Question & Observations \\
\hline 1. & Brief explanation & & & Summarized questionnaire presentation \\
\hline 2. & Personal and professional date & & & Personal and professional information \\
\hline 3. & Knowledge about PA benefits & & 1,4 & $\begin{array}{c}\text { Objective basic knowledge about PAP to } \\
\text { be considered accurate their } \\
\text { following answers. }\end{array}$ \\
\hline 4. & Stage of change on PAP & & 5 & $\begin{array}{c}\text { Stage change on PAP behavior in PHC by } \\
\text { nurses and physicians }\end{array}$ \\
\hline \multirow{25}{*}{5.} & $\begin{array}{l}\text { Self-perception Physical Activity } \\
\text { (PA) pattern of Primary } \\
\text { Healthcare (PHC) staff }\end{array}$ & $\begin{array}{l}\text { Self-perception PA behavior of } \\
\text { PHC professionals }\end{array}$ & 6 & $\begin{array}{l}\text { To check the possibly influence in PAP an } \\
\text { active behavior }\end{array}$ \\
\hline & $\begin{array}{c}\text { Physical Activity on } \\
\text { Prescription (PAP) background }\end{array}$ & PAP knowledge and use & $7,8,9,10$ & $\begin{array}{l}\text { Knowledge and use about PAP by nurses } \\
\text { and primary physicians }\end{array}$ \\
\hline & \multirow{4}{*}{ PHC staff position to PAP } & Leadership to PA promotion & 11,12 & $\begin{array}{l}\text { Leader position in a PA } \\
\text { promotion networking }\end{array}$ \\
\hline & & Leadership to exercise prescription & 14,15 & $\begin{array}{l}\text { Leader position in exercise } \\
\text { prescription networking }\end{array}$ \\
\hline & & Collaborative PA promotion & $13,17,18$ & Collaborative PA promotion networking \\
\hline & & Collaborative exercise prescription & $16,17,18$ & $\begin{array}{l}\text { Collaborative exercise } \\
\text { prescription networking }\end{array}$ \\
\hline & PAP training courses & $\begin{array}{l}\text { PAP training courses status } \\
\text { and necessities }\end{array}$ & $\begin{array}{c}19,20,21,22,23,24 \\
25,26\end{array}$ & $\begin{array}{l}\text { PAP training courses status and resource } \\
\text { necessities in nurses and physicians of } \\
\text { primary healthcare }\end{array}$ \\
\hline & \multirow{2}{*}{$\begin{array}{l}\text { PAP as preventive and } \\
\text { rehabilitation resource }\end{array}$} & PAP awareness by PHC Staff & $8,29.2$ & $\begin{array}{c}\text { Use of PAP in the prevention and } \\
\text { treatment of chronic diseases in } \\
\text { PHC settings }\end{array}$ \\
\hline & & PAP Awareness by patients & 29.6 & $\begin{array}{l}\text { Mass media advices to the patient by } \\
\text { healthcare system }\end{array}$ \\
\hline & \multirow{5}{*}{ PAP barriers } & PAP anamnesis vital sign tool & 27,28 & PA as vital sign in the health tool \\
\hline & & $\begin{array}{l}\text { Improving consultation } \\
\text { time management }\end{array}$ & 29.3 & Time to PAP in PHC consultation \\
\hline & & External policies relationships in PAP & 29.5 & $\begin{array}{l}\text { PAP action plan by the healthcare system } \\
\text { and external institutional relationship }\end{array}$ \\
\hline & & Lack of space resources & 29.1 & $\begin{array}{l}\text { Lack of space to measure fitness and } \\
\text { PA/sedentary levels }\end{array}$ \\
\hline & & Lack of Material-economic resources & 29.4 & Lack of economic and material resources \\
\hline & \multirow{11}{*}{ PAP solutions } & Modify PAP vital sign tool & 30.1 & Add an improved PA vital sign tool \\
\hline & & New space resources & 30.2 & $\begin{array}{l}\text { Add a space to measure fitness and PA } \\
\text { and possible PA training programs }\end{array}$ \\
\hline & & To create PAP networking & 30.3 & Develop a PAP networking \\
\hline & & To offer PAP Training courses & 30.4 & $\begin{array}{l}\text { PAP Training courses to } \\
\text { healthcare professionals }\end{array}$ \\
\hline & & PA advisement policies & 30.5 & PA advisement strategies in mass media \\
\hline & & $\begin{array}{c}\text { Progressive PAP implementation } \\
\text { in PHC }\end{array}$ & 30.6 & $\begin{array}{l}\text { Progressive implantation of PAP in } \\
\text { primary healthcare system }\end{array}$ \\
\hline & & $\begin{array}{l}\text { To enhance material and economic } \\
\text { resources for PAP }\end{array}$ & 30.7 & Add economic resources \\
\hline & & PAP leadership units at PHC & 30.8 & $\begin{array}{l}\text { PAP leader position and structure in the } \\
\text { PHC system }\end{array}$ \\
\hline & & Use of first consultation (nursering) & 30.9 & $\begin{array}{l}\text { Use of first nurse consultation to measure } \\
\text { physical fitness, PA levels, or something } \\
\text { related to PAP }\end{array}$ \\
\hline & & Use of external PHC resources & 30.10 & $\begin{array}{l}\text { Use of space outside PHC settings. i.e., } \\
\text { walking routes, sports centers, etc. }\end{array}$ \\
\hline & & To increase PAP consultation time & 30.11 & $\begin{array}{l}\text { Increase PAP consultation time because } \\
\text { now is insufficient }\end{array}$ \\
\hline
\end{tabular}

The link to the questionnaires (nurses: https://forms.gle/CmJDQAjR5Pt1zLp36; sports medicine physicians https://forms.gle/coQttEgtBPYgH7Qj7) was sent via email, previous consent to participate. Experts had to indicate below each question their degree of agreement (1-5 points in the Likert-type scale, where 5 points indicated the highest agreement and 1 the lowest agreement). When an expert's opinion was $\geq 3 \pm$ standard deviation (SD) different from the mean of the other 9 experts in two or more questions, these values were not considered valid because of the discordance with the rest of experts. The coefficient of content validation for the final 10 experts was calculated using Aiken's V coefficient 
(95\% CI) [40]. This coefficient and the lower and upper confidence intervals were calculated using the free software ICaiken.exe (Visual Basic 6.0, Lima, Perú) [40]. A minimum Aiken's V coefficient score of $\geq 0.75$ was needed for each question to be validated [39].

Table 2. Descriptive data of sports medicine physicians' experts in physical activity on prescription (PAP).

\begin{tabular}{|c|c|c|c|c|c|c|}
\hline Expert & Range Age & Sex & PAP Experience & $\begin{array}{l}\text { Academic } \\
\text { Background }\end{array}$ & $\begin{array}{c}\text { Last University } \\
\text { Studies Finished (Year) }\end{array}$ & $\begin{array}{l}\text { Career Experience } \\
\text { (Years) }\end{array}$ \\
\hline 1 & $51-55$ & Female & Researcher, University professor & Ph.D. & 1985 & 20 \\
\hline 2 & $51-55$ & Female & $\begin{array}{l}\text { University professor, } \\
\text { Healthcare professional }\end{array}$ & Ph.D. & 1988 & 25 \\
\hline 11 * & $56-60$ & Male & $\begin{array}{l}\text { Researcher, University professor, } \\
\text { Healthcare professional }\end{array}$ & Ph.D. & 1983 & 36 \\
\hline 4 & $56-60$ & Male & Healthcare professional & Ph.D. & 1982 & 31 \\
\hline 5 & $>60$ & Female & $\begin{array}{l}\text { Healthcare professional, Public } \\
\text { Health promoter }\end{array}$ & Ph.D. & 1977 & 36 \\
\hline 6 & $56-60$ & Male & $\begin{array}{l}\text { Researcher, University professor, } \\
\text { Healthcare professional }\end{array}$ & Ph.D. & 1986 & 30 \\
\hline 7 & $>60$ & Male & $\begin{array}{c}\text { University professor, } \\
\text { Healthcare professional }\end{array}$ & $\begin{array}{l}\text { Master's degree \& } \\
\text { Bachelor's degree }\end{array}$ & 1984 & 30 \\
\hline 8 & $>60$ & Female & Healthcare professional & Ph.D. & 1981 & 25 \\
\hline 9 & $>60$ & Male & Researcher, University professor & Ph.D. & 1981 & 25 \\
\hline 10 & Total ${ }^{51-55}$ & $\begin{array}{l}\text { Female } \\
50 \% \text { Male }\end{array}$ & Researcher, University professor & Ph.D. & 1989 & $\begin{array}{c}26 \\
28.4 \pm 5.1\end{array}$ \\
\hline
\end{tabular}

$$
\text { * Expert exchanged. }
$$

Table 3. Descriptive data of nurses' experts in physical activity on prescription (PAP).

\begin{tabular}{|c|c|c|c|c|c|c|}
\hline Expert & Range Age & Sex & PAP Experience & $\begin{array}{c}\text { Academic } \\
\text { Background }\end{array}$ & $\begin{array}{c}\text { Last University } \\
\text { Studies Finished (Year) }\end{array}$ & $\begin{array}{c}\text { Career Experience } \\
\text { (Years) }\end{array}$ \\
\hline 1 & $56-60$ & Female & Healthcare professional & Bachelor's degree & 1983 & 35 \\
\hline 2 & $46-50$ & Male & $\begin{array}{l}\text { Researcher, University professor, } \\
\text { Healthcare professional }\end{array}$ & Bachelor's degree & 1982 & 28 \\
\hline 3 & $41-45$ & Female & Researcher, University professor & Ph.D. & 2005 & 19 \\
\hline 4 & $36-40$ & Female & University professor & Ph.D. & 2003 & 10 \\
\hline 5 & $41-45$ & Male & Healthcare professional & $\begin{array}{l}\text { Master's degree \& } \\
\text { Bachelor's degree }\end{array}$ & 1995 & 20 \\
\hline 6 & $41-45$ & Female & Healthcare professional & Bachelor's degree & 1995 & 3 \\
\hline $11 *$ & $36-40$ & Female & Healthcare professional & Master's degree & 2004 & 4 \\
\hline 8 & $46-50$ & Female & $\begin{array}{c}\text { Healthcare professional, Public } \\
\text { Health promoter }\end{array}$ & Master's degree & 2010 & 9 \\
\hline 9 & $36-40$ & Male & Healthcare professional & Bachelor's degree & 2002 & 5 \\
\hline 10 & $51-55$ & Female & Healthcare professional & Master's degree & 1982 & 30 \\
\hline \multicolumn{2}{|r|}{ Total } & $30 \%$ Male & & & & $16.3 \pm 11.8$ \\
\hline
\end{tabular}

* Expert exchanged.

The study was performed according to the principles established with the Declaration of Helsinki 1964 and further amendments and other national regulations for research projects involving human participants: Protection of Personal Data, Law 15/1999 of 13 December on the Protection of Personal Data provided in the current legislation (Royal Decree 1720/2007 of 21 December). The protocol study was approved by the Ethical Committee of the "Hospital Universitario Fundación Alcorcón" and the Central Commission for research of the Region of Madrid (RP1811600040).

\section{Results}

A total 10 sports medicine physicians and 10 nurses with a mean of $28.4 \pm 5.1 \mathrm{y}$ and $16.3 \pm 11.8 \mathrm{y}$ in PAP experience, respectively, were finally considered for the validation of the questionnaires.

The 30 items of each questionnaire were agreed by each expert from 1 to 5 points, being 5 the maximum agreed value. The sports medicine physician expert 3 (Table 4 ) and the expert 7 of the nurses' questionnaire (Table 5) were not considered for offering $3 \pm$ SD answers in $\geq 2$ questions with respect to the mean of the rest of the experts.

To validate both questionnaires, Aiken's $\mathrm{V}$ coefficient values were calculated. For the questionnaires, we obtained a mean value of 0.89 (0.77-1.00) for nurses and $0.84(0.77-0.95)$ for physicians. Results for all items of each questionnaire are shown in Table 6 . The highest $(\geq 0.9)$ Aiken's V coefficient values were obtained for the items, number 1, 5, 8, 13, 19 in both questionnaires (i.e., Supplementary Material Questionnaire S1: GPs' questionnaire). 
Table 4. Values offered by the sports medicine physicians' experts in all questionnaire items for the validation.

\begin{tabular}{|c|c|c|c|c|c|c|c|c|c|c|c|}
\hline & \multicolumn{11}{|c|}{ Sports Medicine Physicians Questionnaire Validation } \\
\hline & Expert 1 & Expert 2 & Expert $11 *$ & Expert 4 & Expert 5 & Expert 6 & Expert 7 & Expert 8 & Expert 9 & Expert 10 & Expert $3 *$ \\
\hline Item 1 & 5 & 5 & 5 & 4 & 4 & 5 & 5 & 5 & 5 & 5 & 5 \\
\hline Item 2 & 5 & 5 & 4 & 2 & 4 & 5 & 5 & 5 & 5 & 4 & 5 \\
\hline Item 3 & 5 & 4 & 3 & 4 & 3 & 5 & 5 & 5 & 5 & 3 & 3 \\
\hline Item 4 & 5 & 5 & 4 & 5 & 3 & 4 & 5 & 5 & 5 & 5 & 4 \\
\hline Item 5 & 4 & 5 & 5 & 5 & 3 & 5 & 5 & 5 & 5 & 5 & 5 \\
\hline Item 6 & 5 & 5 & 3 & 4 & 4 & 5 & 5 & 4 & 5 & 5 & 4 \\
\hline Item 7 & 4 & 5 & 5 & 4 & 4 & 3 & 5 & 5 & 5 & 5 & 5 \\
\hline Item 8 & 4 & 5 & 5 & 4 & 4 & 5 & 5 & 5 & 5 & 5 & 3 \\
\hline Item 9 & 3 & 4 & 3 & 3 & 4 & 5 & 5 & 4 & 5 & 5 & 4 \\
\hline Item 10 & 3 & 4 & 3 & 3 & 4 & 5 & 5 & 5 & 5 & 5 & 4 \\
\hline Item 11 & 4 & 3 & 3 & 4 & 4 & 4 & 5 & 4 & 5 & 5 & 4 \\
\hline Item 12 & 4 & 3 & 4 & 3 & 4 & 5 & 5 & 5 & 5 & 4 & $1^{* *}$ \\
\hline Item 13 & 3 & 4 & 5 & 5 & 4 & 5 & 5 & 5 & 5 & 5 & 3 \\
\hline Item 14 & 4 & 3 & 5 & 5 & 4 & 5 & 5 & 4 & 5 & 4 & 4 \\
\hline Item 15 & 3 & 3 & 5 & 5 & 4 & 5 & 5 & 5 & 5 & 4 & $1 * *$ \\
\hline Item 16 & 3 & 3 & 5 & 5 & 4 & 5 & 5 & 5 & 5 & 5 & 3 \\
\hline Item 17 & 3 & 4 & 4 & 5 & 4 & 5 & 5 & 5 & 5 & 5 & 4 \\
\hline Item 18 & 3 & 4 & 3 & 5 & 4 & 5 & 5 & 4 & 5 & 5 & 3 \\
\hline Item 19 & 3 & 4 & 5 & 5 & 4 & 5 & 5 & 5 & 5 & 5 & 5 \\
\hline Item 20 & 3 & 4 & 5 & 4 & 4 & 5 & 5 & 5 & 5 & 5 & 3 \\
\hline Item 21 & 4 & 3 & 3 & 4 & 4 & 5 & 5 & 5 & 5 & 4 & 4 \\
\hline Item 22 & 3 & 3 & 4 & 4 & 4 & 5 & 5 & 5 & 5 & 4 & 3 \\
\hline Item 23 & 3 & 4 & 3 & 4 & 4 & 5 & 5 & 5 & 5 & 4 & 3 \\
\hline Item 24 & 4 & 4 & 3 & 4 & 3 & 5 & 5 & 5 & 5 & 5 & 2 \\
\hline Item 25 & 4 & 4 & 3 & 4 & 3 & 5 & 5 & 5 & 5 & 5 & 3 \\
\hline Item 26 & 3 & 4 & 3 & 4 & 3 & 5 & 5 & 5 & 5 & 5 & 3 \\
\hline Item 27 & 4 & 4 & 5 & 5 & 4 & 5 & 5 & 3 & 5 & 5 & $1^{* *}$ \\
\hline Item 28 & 3 & 4 & 4 & 4 & 4 & 5 & 5 & 4 & 5 & 5 & $1^{* *}$ \\
\hline Item 29 & 3 & 5 & 4 & 4 & 4 & 5 & 5 & 5 & 3 & 4 & 2 \\
\hline Item 30 & 4 & 4 & 4 & 5 & 4 & 5 & 5 & 5 & 5 & 4 & 4 \\
\hline
\end{tabular}

${ }^{*}$ Expert exchanged; ${ }^{* *}$ values $\geq 3 \pm \mathrm{SD}$ of the mean of the rest of the 9 experts. 
Table 5. Values offered by the nurses' experts in all questionnaire items for the validation.

\begin{tabular}{|c|c|c|c|c|c|c|c|c|c|c|c|}
\hline \multicolumn{12}{|c|}{ Nurses Questionnaire Validation } \\
\hline & Expert 1 & Expert 2 & Expert 3 & Expert 4 & Expert 5 & Expert 6 & Expert $11 *$ & Expert 8 & Expert 9 & Expert 10 & Expert 7 * \\
\hline Item 1 & 5 & 4 & 5 & 4 & 4 & 5 & 4 & 5 & 5 & 5 & 2 \\
\hline Item 2 & 5 & 4 & 3 & 3 & 4 & 5 & 4 & 4 & 4 & 5 & $1 * *$ \\
\hline Item 3 & 5 & 5 & 3 & 5 & 4 & 5 & 4 & 5 & 3 & 5 & 5 \\
\hline Item 4 & 4 & 5 & 4 & 4 & 4 & 5 & 4 & 5 & 5 & 5 & 4 \\
\hline Item 5 & 5 & 4 & 5 & 5 & 5 & 5 & 4 & 4 & 4 & 5 & $1 * *$ \\
\hline Item 6 & 5 & 4 & 3 & 4 & 4 & 5 & 3 & 5 & 5 & 5 & 4 \\
\hline Item 7 & 5 & 4 & 4 & 5 & 4 & 5 & 4 & 3 & 5 & 5 & 4 \\
\hline Item 8 & 5 & 4 & 5 & 5 & 5 & 5 & 3 & 4 & 5 & 5 & 3 \\
\hline Item 9 & 5 & 4 & 4 & 5 & 5 & 5 & 3 & 5 & 5 & 5 & 5 \\
\hline Item 10 & 5 & 4 & 4 & 5 & 4 & 5 & 4 & 4 & 3 & 5 & 5 \\
\hline Item 11 & 5 & 4 & 5 & 4 & 5 & 5 & 4 & 5 & 5 & 5 & 4 \\
\hline Item 12 & 4 & 4 & 4 & 5 & 5 & 5 & 3 & 5 & 3 & 4 & 2 \\
\hline Item 13 & 4 & 5 & 5 & 5 & 5 & 5 & 3 & 5 & 5 & 5 & 4 \\
\hline Item 14 & 5 & 5 & 4 & 5 & 5 & 5 & 4 & 5 & 5 & 5 & 2 \\
\hline Item 15 & 5 & 5 & 4 & 5 & 5 & 5 & 3 & 5 & 4 & 4 & 2 \\
\hline Item 16 & 5 & 5 & 5 & 5 & 5 & 5 & 3 & 5 & 4 & 5 & 4 \\
\hline Item 17 & 5 & 5 & 5 & 4 & 5 & 5 & 4 & 5 & 5 & 5 & 5 \\
\hline Item 18 & 5 & 5 & 5 & 5 & 5 & 5 & 4 & 5 & 5 & 5 & 5 \\
\hline Item 19 & 2 & 5 & 5 & 5 & 5 & 5 & 4 & 5 & 5 & 5 & 5 \\
\hline Item 20 & 5 & 5 & 5 & 5 & 5 & 5 & 4 & 5 & 5 & 5 & 5 \\
\hline Item 21 & 4 & 5 & 4 & 5 & 5 & 5 & 4 & 5 & 5 & 5 & 5 \\
\hline Item 22 & 5 & 5 & 5 & 5 & 5 & 5 & 5 & 5 & 5 & 5 & 5 \\
\hline Item 23 & 5 & 5 & 5 & 5 & 5 & 5 & 4 & 5 & 5 & 5 & 5 \\
\hline Item 24 & 2 & 4 & 4 & 4 & 5 & 5 & 3 & 5 & 4 & 5 & 5 \\
\hline Item 25 & 5 & 5 & 4 & 5 & 5 & 5 & 4 & 5 & 5 & 5 & 5 \\
\hline Item 26 & 2 & 5 & 2 & 4 & 5 & 5 & 3 & 5 & 4 & 5 & 5 \\
\hline Item 27 & 3 & 5 & 2 & 4 & 5 & 5 & 4 & 1 & 5 & 5 & 3 \\
\hline Item 28 & 5 & 5 & 3 & 4 & 5 & 5 & 4 & 2 & 5 & 5 & 4 \\
\hline Item 29 & 4 & 4 & 5 & 5 & 5 & 5 & 4 & 5 & 5 & 5 & 5 \\
\hline Item 30 & 5 & 5 & 5 & 5 & 5 & 5 & 4 & 5 & 5 & 5 & 5 \\
\hline
\end{tabular}

${ }^{*}$ Expert exchanged; ** values $\geq 3 \pm \mathrm{SD}$ of the mean of rest 9 experts. 
Table 6. The mean and Aiken's V coefficient score for all the thirty items offered by the ten experts.

\begin{tabular}{|c|c|c|c|c|c|c|c|c|c|c|c|c|c|c|}
\hline \multirow[b]{2}{*}{ Item } & \multicolumn{7}{|c|}{ GPs' Questionnaire } & \multicolumn{7}{|c|}{ Nurses' Questionnaire } \\
\hline & 1 & 2 & 3 & 4 & 5 & Mean & $\begin{array}{c}\text { Aiken's V (95\% CI *) } \\
\text { Value (Range) }\end{array}$ & 1 & 2 & 3 & 4 & 5 & Mean & $\begin{array}{c}\text { Aiken's V (95\% CI *) } \\
\text { Value (Range) }\end{array}$ \\
\hline 1 & 0 & 0 & 0 & 2 & 8 & 4.80 & $0.95(0.83-0.98)$ & 0 & 0 & 0 & 4 & 6 & 4.60 & $0.90(0.76-0.96)$ \\
\hline 2 & 0 & 1 & 0 & 3 & 6 & 4.40 & $0.85(0.70-0.92)$ & 0 & 0 & 2 & 5 & 3 & 4.10 & $0.77(0.62-0.87)$ \\
\hline 3 & 0 & 0 & 3 & 2 & 5 & 4.20 & $0.80(0.65-0.89)$ & 0 & 0 & 2 & 2 & 6 & 4.40 & $0.85(0.70-0.92)$ \\
\hline 4 & 0 & 0 & 1 & 2 & 7 & 4.60 & $0.90(0.76-0.96)$ & 0 & 0 & 0 & 5 & 5 & 4.50 & $0.87(0.73-0.94)$ \\
\hline 5 & 0 & 0 & 1 & 1 & 8 & 4.70 & $0.92(0.80-0.97)$ & 0 & 0 & 0 & 4 & 6 & 4.60 & $0.90(0.76-0.96)$ \\
\hline 6 & 0 & 0 & 1 & 3 & 6 & 4.50 & $0.87(0.73-0.94)$ & 0 & 0 & 2 & 3 & 5 & 4.30 & $0.82(0.68-0.91)$ \\
\hline 7 & 0 & 0 & 1 & 3 & 6 & 4.50 & $0.87(0.73-0.94)$ & 0 & 0 & 1 & 4 & 5 & 4.40 & $0.85(0.70-0.92)$ \\
\hline 8 & 0 & 0 & 0 & 3 & 7 & 4.70 & $0.92(0.80-0.97)$ & 0 & 0 & 1 & 2 & 7 & 4.60 & $0.90(0.76-0.96)$ \\
\hline 9 & 0 & 0 & 3 & 3 & 4 & 4.10 & $0.77(0.62-0.87)$ & 0 & 0 & 1 & 2 & 7 & 4.60 & $0.90(0.76-0.96)$ \\
\hline 10 & 0 & 0 & 3 & 2 & 5 & 4.20 & $0.80(0.65-0.89)$ & 0 & 0 & 1 & 5 & 4 & 4.30 & $0.82(0.68-0.91)$ \\
\hline 11 & 0 & 0 & 2 & 5 & 3 & 4.10 & $0.77(0.62-0.87)$ & 0 & 0 & 0 & 3 & 7 & 4.70 & $0.92(0.80-0.97)$ \\
\hline 12 & 0 & 0 & 2 & 4 & 4 & 4.20 & $0.80(0.65-0.89)$ & 0 & 0 & 2 & 4 & 4 & 4.20 & $0.80(0.65-0.89)$ \\
\hline 13 & 0 & 0 & 1 & 2 & 7 & 4.60 & $0.90(0.76-0.96)$ & 0 & 0 & 1 & 1 & 8 & 4.70 & $0.92(0.80-0.97)$ \\
\hline 14 & 0 & 0 & 1 & 4 & 5 & 4.40 & $0.85(0.70-0.92)$ & 0 & 0 & 0 & 2 & 8 & 4.80 & $0.95(0.83-0.98)$ \\
\hline 15 & 0 & 0 & 2 & 2 & 6 & 4.40 & $0.85(0.70-0.92)$ & 0 & 0 & 0 & 3 & 6 & 4.50 & $0.87(0.73-0.94)$ \\
\hline 16 & 0 & 0 & 2 & 1 & 7 & 4.50 & $0.87(0.73-0.94)$ & 0 & 0 & 1 & 1 & 8 & 4.70 & $0.92(0.80-0.97)$ \\
\hline 17 & 0 & 0 & 1 & 3 & 6 & 4.50 & $0.87(0.73-0.94)$ & 0 & 0 & 0 & 2 & 8 & 4.80 & $0.95(0.83-0.98)$ \\
\hline 18 & 0 & 0 & 2 & 3 & 5 & 4.30 & $0.82(0.68-0.91)$ & 0 & 0 & 0 & 1 & 9 & 4.90 & $0.97(0.87-0.99)$ \\
\hline 19 & 0 & 0 & 1 & 2 & 7 & 4.60 & $0.90(0.76-0.96)$ & 0 & 1 & 0 & 1 & 8 & 4.60 & $0.90(0.76-0.96)$ \\
\hline 20 & 0 & 0 & 1 & 3 & 6 & 4.5 & $0.87(0.73-0.94)$ & 0 & 0 & 0 & 1 & 9 & 4.90 & $0.97(0.87-0.99)$ \\
\hline 21 & 0 & 0 & 2 & 4 & 4 & 4.20 & $0.80(0.65-0.89)$ & 0 & 0 & 0 & 3 & 7 & 4.70 & $0.92(0.80-0.97)$ \\
\hline 22 & 0 & 0 & 2 & 4 & 4 & 4.20 & $0.80(0.65-0.89)$ & 0 & 0 & 0 & 0 & 10 & 5.00 & $1.00(0.91-1.00)$ \\
\hline 23 & 0 & 0 & 2 & 4 & 4 & 4.20 & $0.80(0.65-0.89)$ & 0 & 0 & 0 & 1 & 9 & 4.90 & $0.97(0.87-0.99)$ \\
\hline 24 & 0 & 0 & 2 & 3 & 5 & 4.30 & $0.82(0.68-0.91)$ & 0 & 1 & 1 & 4 & 4 & 4.10 & $0.77(0.62-0.87)$ \\
\hline 25 & 0 & 0 & 2 & 3 & 5 & 4.30 & $0.82(0.68-0.91)$ & 0 & 0 & 0 & 2 & 8 & 4.80 & $0.95(0.83-0.98)$ \\
\hline 26 & 0 & 0 & 2 & 4 & 4 & 4.20 & $0.80(0.65-0.89)$ & 0 & 1 & 2 & 2 & 5 & 4.10 & $0.77(0.62-0.87)$ \\
\hline 27 & 0 & 0 & 1 & 3 & 6 & 4.50 & $0.87(0.73-0.94)$ & 0 & 1 & 2 & 2 & 5 & 4.10 & $0.77(0.62-0.87)$ \\
\hline 28 & 0 & 0 & 1 & 5 & 4 & 4.30 & $0.82(0.68-0.91)$ & 0 & 1 & 1 & 2 & 6 & 4.30 & $0.82(0.68-0.91)$ \\
\hline 29 & 0 & 0 & 2 & 4 & 4 & 4.20 & $0.80(0.65-0.89)$ & 0 & 0 & 0 & 3 & 7 & 4.70 & $0.92(0.80-0.97)$ \\
\hline 30 & 0 & 0 & 0 & 5 & 5 & 4.50 & $0.87(0.73-0.94)$ & 0 & 0 & 0 & 0 & 1 & 4.90 & $0.97(0.87-0.99)$ \\
\hline Total & & & & & & & $0.84(\mathrm{SD} \pm 0.04)$ & & & & & & & $0.89(\mathrm{SD} \pm 0.06)$ \\
\hline
\end{tabular}

The Likert scale varied from 1 to 5 , where the minimum (1) value is according to a very poor relevance and the maximum (5) to the highest degree of relevance. CI * confidence intervals. GPs: general practitioners. 


\section{Discussion}

The both choice-modeling Google-form questionnaires about self-perception of PAP barriers and facilitators by nurses and physicians were validated after a previous design following a rigorous method based on a content-analysis processing of two verbatim transcribed focus group sessions [12].

Item 1, focused on the preventive health benefits of PA and exercise, could discriminate if HC professionals do or do not promote PA, because of the lack of knowledge about the benefits or for other reasons still not resolved. However, the scientific literature provides clear evidence about the benefits of PA on human health [2-4]. PAP interventions in PCH settings have still a reduced evidence and need to be enhanced [41]. Previously, Desveaux et al. proposed a questionnaire to find facilitators and barriers of patients and HC providers in regard to a community-based exercise program [29], in a similar way than Myles et al., in Canada [36], Bock et al., in Germany [30], Freene et al., in Austalia [35], and Oyeyemi et al., in Nigeria [37]. Trying to filling in the gap, we propose a new validated questionnaire for analyzing feasibility of PAP in HC settings considering all dimensions and their respective integrated factors, according to the WHO 5 dimensions adherence model [16,42].

Item 5 was designed to assess the stage of change on PAP behavior for PHC professionals, according to the stage of changes of the transtheoretical model [43]. This question was introduced because many studies have evaluated the lifestyle behavior changes in patients or people [44,45], although currently to produce changes towards positive healthy lifestyles for a long-term time is not recognized as an efficient strategy in HC settings [45]. The participants of the previous focus group interview sessions [12] showed a lack of awareness as the majority of their professional colleagues. Because of this, the item tries to assess PAP behavior, based on the 5 stages of change behavior (pre-contemplation, contemplation, preparation, action, maintenance) in PHC providers. WHO proposed already in 2003 that health professionals need to be trained in non-pharmacological adherence treatments [16]. In order to improve adherence levels to PAP as a non-pharmacological treatment, to know what happens with patients is as important as to know about PHC staff. The panel of experts who validated the questionnaires seems to agree with this. Item 8 of the questionnaire was designed to assess the awareness on PAP by health professionals regarding the potential influence with their patients [24,25]. The experts agreed with the relevance of the question to be considered as an indicator in the self-perception barrier of PHC professionals in PAP. Item 13 asked about how PHC professionals were willing to collaborate in PA promotion through a multidisciplinary PHC team. This was scored as important by the experts, in line with the Exercise is Medicine initiative, which encourages multidisciplinarity [8,9]. Finally, item 19, related to the interest on PAP training courses for PHC professionals, was highly scored by all experts, being an indicator to enhance the efficient PAP implementation in PHC settings in accordance with previous studies $[23,46,47]$. Additionally, other training courses were demanded by the professionals, related to motivational interviews for PAP and time management and identified as resources needed to establish PAP efficiently in PHC settings, in accordance with other authors [48-50]. Therefore, this item was also included in the questionnaire and scored high by the experts.

This study could offer the key point to establish a validated questionnaire to analyze the main barriers of nurses and physicians at PHC settings to use PAP in their consultations under their self-perception, as a key factor, according to the social-ecological model [27]. In addition, knowing the positive predisposition of all PHC respondents, especially physicians, to collaborate with other health promoters and local community resources, these questions could be used to find the facilitators to design an effective PAP strategy to implement PAP in PHC settings, according to the health necessities and such as is proposed by recent European and global initiatives [6,51,52]. Limitations for this study were the equivalence on contents offered in the questions for nurses and physicians, according to the similitude of results in the content analysis of the semi-structured focus group sessions developed with them. This study has several strengths, as the validation procedure is based on a rigorous qualitative research process and the experts are highly prestigious in their fields. In a further study, a similar questionnaire process could be developed with exercise professionals in order to establish the self-perceived barriers and facilitators for an interdisciplinary PAP implementation team at HC settings. 


\section{Conclusions}

The two 30 choice-modeling questions of the Google-form questionnaires have been validated by a panel of 10 experts and both are ready to be used in PHC systems to assess the self-perception of PAP facilitators and barriers of nurses and general practitioners. This should lead to facilitate the implementation of an efficient cost-effective and useful public health strategy in the HC system according to the Exercise is Medicine strategy.

Supplementary Materials: The following are available online at http://www.mdpi.com/1660-4601/17/18/6627/s1, Questionnaire S1: GPs' questionnaire.

Author Contributions: Conceptualization, S.C.-P., F.F.-J. and M.G.-G.; Methodology, S.C.-P., F.F.-J.; Software, S.C.-P.; Validation, S.C.-P.; Formal Analysis, S.C.-P.; Investigation, S.C.-P., F.F.-J and M.G.-G.; Resources, S.C.-P. and M.G.-G.; Data Curation, S.C.-P. and F.F.-J.; Writing-Original Draft Preparation, S.C.-P.; Writing - Review \& Editing, S.C.-P., F.F.-J., J.A.C.M. and M.G.-G.; Visualization, J.A.C.M., and M.G.-G.; Supervision, J.A.C.M., and M.G.-G.; Project Administration, J.A.C.M., and M.G.-G.; Funding Acquisition, J.A.C.M. and M.G.-G. All authors have read and agreed to the published version of the manuscript.

Funding: This research received no external funding.

Acknowledgments: We would like to thank to all experts who offered their help to validate both questionnaires selflessly and the EXERNET Research Network on Physical Activity and Health for supporting this study.

Conflicts of Interest: The authors declare no conflict of interest.

\section{References}

1. Guthold, R.; Stevens, G.A.; Riley, L.M.; Bull, F.C. Worldwide trends in insufficient physical activity from 2001 to 2016: A pooled analysis of 358 population-based surveys with 1.9 million participants. Lancet Glob. Health 2018, 6, e1077-e1086. [CrossRef]

2. Booth, F.W.; Roberts, C.K.; Thyfault, J.P.; Ruegsegger, G.N.; Toedebusch, R.G. Role of Inactivity in Chronic Diseases: Evolutionary Insight and Pathophysiological Mechanisms. Physiol. Rev. 2017, 97, 1351-1402. [CrossRef] [PubMed]

3. Pedersen, B.K.; Saltin, B. Exercise as medicine-evidence for prescribing exercise as therapy in 26 different chronic diseases. Scand. J. Med. Sci. Sports 2015, 25, 1-72. [CrossRef] [PubMed]

4. Ramírez-Vélez, R.; Lobelo, F.; Izquierdo, M. Exercise for Disease Prevention and Management: A Precision Medicine Approach. J. Am. Med. Dir. Assoc. 2017, 18, 633-634. [CrossRef]

5. Thornton, J.; Frémont, P.; Khan, K.; Poirier, P.; Fowles, J.; Wells, G.D.; Frankovich, R.J. Physical activity prescription: A critical opportunity to address a modifiable risk factor for the prevention and management of chronic disease: A position statement by the Canadian Academy of Sport and Exercise Medicine: Table 1. Br. J. Sports Med. 2016, 50, 1109-1114. [CrossRef]

6. WHO. Physical Activity Strategy for the WHO European Region 2016-2025. Available online: www.euro. who.int/_data/assets/pdf_file/0010/282961/65wd09e_PhysicalActivityStrategy_150474.pdf?ua=1 (accessed on 5 November 2018).

7. Fowles, J.; O'Brien, M.W.; Solmundson, K.; Oh, P.I.; Shields, C.A. Exercise is Medicine Canada physical activity counselling and exercise prescription training improves counselling, prescription, and referral practices among physicians across Canada. Appl. Physiol. Nutr. Metab. 2018, 43, 535-539. [CrossRef]

8. Heath, G.W.; Kolade, V.O.; Haynes, J.W. Exercise is Medicine ${ }^{\mathrm{TM}}$ : A pilot study linking primary care with community physical activity support. Prev. Med. Rep. 2015, 2, 492-497. [CrossRef]

9. Lobelo, F.; Stoutenberg, M.; Hutber, A. The Exercise is Medicine Global Health Initiative: A 2014 update. Br. J. Sports Med. 2014, 48, 1627-1633. [CrossRef]

10. Lion, A.; Vuillemin, A.; Thornton, J.S.; Theisen, D.; Stranges, S.; Ward, M. Physical activity promotion in primary care: A Utopian quest? Health Promot. Int. 2018, 34, 877-886. [CrossRef]

11. Ward, M. Health Enhancing Physical Activity (HEPA) Promotion in Health Care Settings, Policy, Practice \& Evidence; HEPA Europe Working Group: Wales, UK, 2016. 
12. Pascual, S.C. Context analysis in the development for future implementation of Exercise is Medicine ${ }^{\circledR}$ initiative as prevention and treatment resource for chronic diseases at Primary Healthcare settings. In Health and Human Performance 2019; Facultad de Ciencias de la Actividad Física y del Deporte (INEF), Universidad Politécnica de Madrid: Madrid, Spain, 2019; p. 291.

13. Bull, F.; Milton, K.; Kahlmeier, S.; Arlotti, A.; Juričan, A.B.; Belander, O.; Martin, B.; Martin-Diener, E.; Marques, A.; Mota, J.; et al. Turning the tide: National policy approaches to increasing physical activity in seven European countries. Br. J. Sports Med. 2015, 49, 749-756. [CrossRef]

14. Morgan, F.M.; Battersby, A.; Weightman, A.L.; Searchfield, L.; Turley, R.L.; Morgan, H.; Jagroo, J.; Ellis, S. Adherence to exercise referral schemes by participants-What do providers and commissioners need to know? A systematic review of barriers and facilitators. BMC Public Health 2016, 16, 227. [CrossRef] [PubMed]

15. Moore, L.; Moore, L.A.; Murphy, S. Facilitating adherence to physical activity: Exercise professionals' experiences of the National Exercise Referral Scheme in Wales. A qualitative study. BMC Public Health 2011, 11, 935. [CrossRef] [PubMed]

16. WHO. Adherence to Long-Term Therapies: Evidence for Action. 2003. Available online: Apps.who.int/iris/ bitstream/10665/42682/1/9241545992.pdf (accessed on 1 January 2018).

17. Persson, G.; Brorsson, A.; Hansson, E.E.; Troein, M.; Strandberg, E.L. Physical activity on prescription (PAP) from the general practitioner's perspective-A qualitative study. BMC Fam. Pract. 2013, 14, 128. [CrossRef] [PubMed]

18. Puig-Ribera, A.; Martín-Cantera, C.; Puigdomènech, E.; Real, J.; Romaguera, M.; Magdalena-Belio, J.F.; Recio-Rodríguez, J.I.; Rodriguez-Martin, B.; Arietaleanizbeaskoa, M.S.; Repiso-Gento, I.; et al. Screening Physical Activity in Family Practice: Validity of the Spanish Version of a Brief Physical Activity Questionnaire. PLoS ONE 2015, 10, e0136870. [CrossRef]

19. Blackstock, F.C.; ZuWallack, R.; Nici, L.; Lareau, S.C. Why Don't Our Patients with Chronic Obstructive Pulmonary Disease Listen to Us? The Enigma of Nonadherence. Ann. Am. Thorac. Soc. 2016, 13, 317-323. [CrossRef] [PubMed]

20. Pascual, S.C.; Mallén, J.A.C.; Gross, M.G. La Actividad Física en el Currículo Universitario Español de los Grados de Medicina y Ciencias de la Actividad Física y del Deporte Como Recurso en la Prevención y Tratamiento de las Enfermedades Crónicas. Nutr. Hosp. 2017, 34, 961-968. [CrossRef]

21. Weiler, R.; Chew, S.; Coombs, N.; Hamer, M.; Stamatakis, E. Physical activity education in the undergraduate curricula of all UK medical schools. Are tomorrow's doctors equipped to follow clinical guidelines? Br. J. Sports Med. 2012, 46, 1024-1026. [CrossRef]

22. Dacey, M.; Kennedy, M.A.; Polak, R.; Phillips, E.M. Physical activity counseling in medical school education: A systematic review. Med. Educ. Online 2014, 19, 24325. [CrossRef]

23. Hill, L.L.; Nichols, J.; Wing, D.; Waalen, J.; Friedman, E. Training on Exercise is Medicine((R)) Within an Integrative Medicine Curriculum. Am. J. Prev. Med. 2015, 49 (Suppl. 3), S278-S284. [CrossRef]

24. AuYoung, M.; Linke, S.E.; Pagoto, S.; Buman, M.P.; Craft, L.L.; Richardson, C.R.; Hutber, A.; Marcus, B.H.; Estabrooks, P.; Gorin, S.S. Integrating Physical Activity in Primary Care Practice. Am. J. Med. 2016, 129, 1022-1029. [CrossRef]

25. Barnes, P.M.; Schoenborn, C.A. Trends in adults receiving a recommendation for exercise or other physical activity from a physician or other health professional. NCHS Data Brief 2012, 8, 1-8.

26. McLeroy, K.R.; Bibeau, D.L.; Steckler, A.; Glanz, K. An Ecological Perspective on Health Promotion Programs. Health Educ. Q. 1988, 15, 351-377. [CrossRef] [PubMed]

27. Burke, S.; Utley, A.; Belchamber, C.; McDowall, L. Physical Activity in Hospice Care: A Social Ecological Perspective to Inform Policy and Practice. Res. Q. Exerc. Sport 2020, 91, 500-513. [CrossRef]

28. Viana, A.G. Evaluación de la Implementación a Escala del Plan de Actividad Física, Deporte y Salud; Departament de Ciencies Experimentals i de la Salud, Universitat Pompeu Fabra: Barcelona, Spain, 2018; p. 332.

29. Desveaux, L.; Goldstein, R.; Mathur, S.; Brooks, D. Barriers to Physical Activity Following Rehabilitation: Perspectives of Older Adults with Chronic Disease. J. Aging Phys. Act. 2016, 24, 223-233. [CrossRef] [PubMed]

30. Bock, C.; Diehm, C.; Schneider, S. Physical activity promotion in primary health care: Results from a German physician survey. Eur. J. Gen. Pract. 2012, 18, 86-91. [CrossRef] 
31. Curbach, J.; Apfelbacher, C.; Knoll, A.; Herrmann, S.; Szagun, B.; Loss, J. Physicians' perspectives on implementing the prevention scheme "Physical Activity on Prescription": Results of a survey in Bavaria. Zeitschrift für Evidenz, Fortbildung und Qualität im Gesundheitswesen 2018, 131-132, 66-72. [CrossRef]

32. Pojednic, R.M.; Polak, R.; Arnstein, F.; Kennedy, M.A.; Bantham, A.; Phillips, E.M. Practice patterns, counseling and promotion of physical activity by sports medicine physicians. J. Sci. Med. Sport 2017, 20, 123-127. [CrossRef]

33. Pojednic, R.; Bantham, A.; Arnstein, F.; Kennedy, M.A.; Phillips, E. Bridging the gap between clinicians and fitness professionals: A challenge to implementing exercise as medicine. BMJ Open Sport Exerc. Med. 2018, 4, e000369. [CrossRef]

34. Shirley, D.; Van Der Ploeg, H.P.; Bauman, A.E. Physical Activity Promotion in the Physical Therapy Setting: Perspectives from Practitioners and Students. Phys. Ther. 2010, 90, 1311-1322. [CrossRef]

35. Freene, N.; Cools, S.; Hills, D.; Bissett, B.; Pumpa, K.L.; Cooper, G.M. A wake-up call for physical activity promotion in Australia: Results from a survey of Australian nursing and allied health professionals. Aust. Health Rev. 2019, 43, 165. [CrossRef]

36. O’Brien, M.W.; Shields, C.A.; Campbell, K.L.; Crowell, S.J.; Fowles, J. Perceptions and Practices of Providing Physical Activity Counselling and Exercise Prescriptions among Physiotherapists in Nova Scotia. Physiother. Can. 2019, 72, 230-238. [CrossRef]

37. Oyeyemi, A.L.; Oyeyemi, A.Y.; Habib, R.Y.; Usman, R.B.; Sunday, J.U.; Usman, Z. A survey of physicians and physiotherapists on physical activity promotion in Nigeria. Arch. Physiother. 2017, 7, 5. [CrossRef] [PubMed]

38. Tsang, S.; Royse, C.F.; Terkawi, A.S. Guidelines for developing, translating, and validating a questionnaire in perioperative and pain medicine. Saudi J. Anaesth. 2017, 11 (Suppl. 1), S80-S89. [CrossRef]

39. Jiménez-Rubio, S.; Navandar, A.; Rivilla-García, J.; Paredes-Hernández, V. Validity of an On-Field Readaptation Program Following a Hamstring Injury in Professional Soccer. J. Sport Rehabil. 2019, 28, 1-7. [CrossRef]

40. Merino-Soto, C. Confidence interval for difference between coefficients of content validity (Aiken's V): A SPSS syntax. An. Psicol. Ann. Psychol. 2018, 34, 587-590.

41. Sánchez-López, M.; Bully, P.; Martínez, C.; Grandes, G. Effectiveness of physical activity promotion interventions in primary care: A review of reviews. Prev. Med. 2015, 76, S56-S67. [CrossRef] [PubMed]

42. Venegas, M.; Carrasco, B.; Casas-Cordero, R. Factors influencing long-term adherence to pelvic floor exercises in women with urinary incontinence. Neurourol. Urodyn. 2017, 37, 1120-1127. [CrossRef]

43. Hutchison, A.J.; Breckon, J.D.; Johnston, L.H. Physical Activity Behavior Change Interventions Based on the Transtheoretical Model: A Systematic Review. Health Educ. Behav. 2009, 36, 829-845. [CrossRef]

44. Murray, J.M.; Brennan, S.F.; French, D.P.; Patterson, C.C.; Kee, F.; Hunter, R.F. Mediators of Behavior Change Maintenance in Physical Activity Interventions for Young and Middle-Aged Adults: A Systematic Review. Ann. Behav. Med. 2018, 52, 513-529. [CrossRef]

45. Bully, P.; Sánchez-López, M.; Zabaleta-Del-Olmo, E.; Pombo-Ramos, H.; Grandes, G. Evidence from interventions based on theoretical models for lifestyle modification (physical activity, diet, alcohol and tobacco use) in primary care settings: A systematic review. Prev. Med. 2015, 76, S76-S93. [CrossRef]

46. Dunlop, M.; Murray, A.D. Major limitations in knowledge of physical activity guidelines among UK medical students revealed: Implications for the undergraduate medical curriculum. Br. J. Sports Med. 2013, 47, 718-720. [CrossRef] [PubMed]

47. Stoutenberg, M.; Stasi, S.; Stamatakis, E.; Danek, D.; Dufour, T.; Trilk, J.L.; Blair, S.N. Physical activity training in US medical schools: Preparing future physicians to engage in primary prevention. Physician Sportsmed. 2015, 43, 388-394. [CrossRef] [PubMed]

48. Ribera, A.P.; McKenna, J.; Riddoch, C. Attitudes and practices of physicians and nurses regarding physical activity promotion in the Catalan primary health-care system. Eur. J. Public Health 2005, 15, 569-575. [CrossRef]

49. Johansson, H.; Stenlund, H.; Lundström, L.; Weinehall, L. Reorientation to more health promotion in health services-A study of barriers and possibilities from the perspective of health professionals. J. Multidiscip. Healthc. 2010, 3, 213-224. [CrossRef] [PubMed]

50. Leenaars, K.; Smit, E.; Wagemakers, A.; Molleman, G.; Koelen, M. Facilitators and barriers in the collaboration between the primary care and the sport sector in order to promote physical activity: A systematic literature review. Prev. Med. 2015, 81, 460-478. [CrossRef] [PubMed] 
51. WHO. Ottawa Charter for Health Promotion. Health Promot. 1986, 1, iii-v.

52. WHO. World Health Organization Global Recommendations on Physical Activity for Health; WHO: Geneva, Switzerland, 2010.

() 8

(C) 2020 by the authors. Licensee MDPI, Basel, Switzerland. This article is an open access article distributed under the terms and conditions of the Creative Commons Attribution (CC BY) license (http://creativecommons.org/licenses/by/4.0/). 